\title{
Rinosinusitis Alergi pada Hipertiroidisme
}

\author{
Orlena Dharmantary Kartika, Sinta Sari Ratunanda, Teti Madiadipoera
}

Departemen Ilmu Telinga Hidung Tenggorokan Kepala Leher, Fakultas Kedokteran, Universitas Padjadjaran/ Rumah Sakit Umum Dr. Hasan Sadikin, Bandung, Indonesia

\begin{abstract}
Abstrak
Prevalensi penyakit alergi semakin meningkat di seluruh dunia, tetapi hubungan dan pengaruhnya dengan penyakit tiroid autoimun khususnya hipertiroidisme masih belum banyak dibahas dan dimunculkan kasusnya. Kasus ini diajukan untuk memberikan gambaran bahwa rinosinusitis alergi dan penyakit tiroid autoimun khususnya hipertiroidisme memiliki satu mata rantai yang saling berhubungan dari segi patofisiologi dan akan menentukan morbiditas hipertiroidisme tersebut. Dilaporkan dua kasus rinosinusitis alergi disertai hipertiroidisme. Kasus pertama wanita usia 64 tahun dengan benjolan di leher anterior, dan kasus kedua pasien pria usia 61 tahun yang dikonsulkan dari Poliklinik Endokrinologi Penyakit Dalam dengan keluhan utama hidung tersumbat. Penatalaksanaan pada kedua pasien dilakukan pemeriksaan skor total gejala hidung, penilaian kualitas hidup dengan SNOT-22, pemeriksaan nasoendoskopi dan Tes Kulit Tusuk (TKT), serta pemantauan kadar hormon tiroid dan konsumsi obat antitiroid, kemudian dilakukan tata laksana rinosinusitis alergi dengan pemberian cuci hidung, antibiotik, kortikosteroid intranasal, dan antihistamin generasi kedua. Didapatkan hasil penurunan skor total gejala hidung, perbaikan kualitas hidup, perbaikan secara nasoendoskopi, penurunan kadar hormon tiroid, serta penurunan konsumsi obat antitiroid. Kesimpulan Rinosinusitis alergi pada hipertiroidisme harus ditangani dengan baik karena dengan mengatasi rinosinusitis alergi maka akan menurunkan morbiditas hipertiroidisme.
\end{abstract}

Kata kunci : Rinosinusitis alergi, penyakit tiroid autoimun, hipertiroidisme

\section{Allergic Rhinosinusitis in Hyperthyroidism}

\begin{abstract}
The prevalence of allergic disease is increasing worldwide, but the correlation and influence with autoimmune thyroid disease especially hyperthyroidism is still not widely discussed. This case is to remind about allergic rhinosinusitis and autoimmune thyroid disease especially hyperthyroidism have a connection from their pathophysiology and it will determine the autoimmune thyroid disease's morbidity. We reported two cases of allergic rhinosinusitis in hyperthyroidism patients, the first case is 64 years old woman with lump at front neck region and the second case is 61 years old man consulted from endocrinologist with blocking nose symptom. Management on both patients, we performed total nasal symptom score, quality of life scoring with SNOT-22, nasoendoscopic examination, Skin Prick Test, thyroid hormone level and antithyroid drug consumption monitoring, and then we treat both patients with allergic rhinosinusitis management nasal wash with isotonic solution, antibiotic, intranasal corticosteroid, and second generation antihistamin. The results are decreasing of total nasal symptom score, better quality of life, improvement of nasoendoscopic's finding, decreasing of thyroid hormone level, and remission of antithyroid drug consumption. Conclusion: Allergic rhinosinusitis in hyperthyroidism must be solved properly because with overcoming the allergic rhinosinusitis then the hyperthyroidism's morbidity will be decreased.
\end{abstract}

Keywords : Allergic rhinosinusitis, autoimmune thyroid disease, hyperthyroidism

\author{
Korespondensi: \\ Orlena Dharmantary Kartika, dr \\ Departemen IImu Telinga Hidung Tenggorokan Kepala Leher, Fakultas Kedokteran, Universitas Padjadjaran/ \\ Rumah Sakit Umum Dr. Hasan Sadikin, Bandung, Indonesia \\ Jl. Pasteur No. 38, Kota Bandung, 40161 \\ Mobile : 081210020448 \\ Email :dr.orlena@gmail.com
}




\section{Pedahuluan}

Rinitis alergi dan hipertiroidisme adalah dua penyakit yang cukup tinggi prevalensinya dan terus meningkat. Prevalensi rinitis alergi diperkirakan $10 \%$ - $30 \%$ populasi atau lebih dari 500 juta penduduk dunia, namun jumlah tersebut berbeda pada setiap negara. Perkiraan prevalensi dari sensitisasi IgE oleh aeroalergen spesifik baik serum maupun tes kulit lebih dari $40 \%$ populasi.1 Prevalensi rinitis alergi di Asia sebesar $45 \%$, terutama di negara-negara berkembang termasuk Indonesia. Berdasarkan data yang ada, terlihat bahwa sebanyak $10-30 \%$ penduduk dewasa mengalami rinitis alergi. ${ }^{2}$ Namun angka prevalensi ini juga dipengaruhi oleh faktor genetik, geografik, iklim, dan juga alergen dominan yang ada di daerah tersebut. Sebanyak 167 pasien yang datang ke Poliklinik Rinologi Alergi THT-KL RS Dr. Hasan Sadikin Bandung dari tahun 2010-2012 didiagnosis menderita rinitis alergi. Sebagian besar pasien berusia 18-34 tahun $(52,7 \%), 14,4 \%$ berusia $35-49$ tahun, dan sebanyak 52\% mengalami rinitis alergi persisten sedang-berat berdasarkan Allergic Rhinitis and Its Impact on Asthma-World Health Organization (ARIA-WHO). ${ }^{3}$

Penyebab tersering dari hipertiroidisme adalah penyakit Graves, yang memiliki prevalensi hingga $80 \%$ dari seluruh kasus hipertiroidisme. Penyakit ini terjadi pada $0,5 \%$ populasi di seluruh dunia, dimana terjadi pembesaran kelenjar tiroid, sekresi hormon tiroid yang berlebih dan dampak ekstratiroidal yang bervariasi mulai dari oftalmopati hingga akropati tiroid. Onset penyakit ini biasanya terjadi antara usia 20 hingga 50 tahun dan wanita 5 - 10 kali lebih sering dibanding pria. ${ }^{4}$

Penyakit Graves merupakan suatu penyakit autoimun yakni tubuh secara berlebihan membentuk thyroid-stimulating immunoglobulin (TSI), suatu antibodi yang sasarannya adalah reseptor TSH di sel tiroid. TSI merangsang sekresi dan pertumbuhan tiroid dengan cara serupa yang dilakukan oleh TSH. Namun tidak seperti TSH, TSI tidak dipengaruhi oleh inhibisi umpan balik negatif oleh hormon tiroid, sehingga sekresi dan pertumbuhan hormon tiroid terus berlangsung. ${ }^{4}$

Terdapat beberapa kondisi kelainan endokrin yang dapat muncul bersamaan dengan gejala dan tanda alergi. Kondisi kelainan hormon tiroid bervariasi dari kelelahan hingga orbitopati terkait dengan penyakit Graves yang dapat dikacaukan dengan konjungtivitis alergi dan angioedema. ${ }^{5}$

Berdasarkan penelitian yang dilakukan oleh Reisacher WR terdapat hubungan yang jelas antara penyakit tiroid autoimun dengan rinitis alergi. Berdasarkan literatur, hubungannya meluas hingga ke riwayat atopik yang mendasari rinitis alergi. Namun bagaimanapun penelitian lain mengungkapkan bahwa hubungan yang terkait di antara keduanya adalah dari parameter subklinis, seperti kadar serum antibodi. ${ }^{6}$

Kasus ini diajukan untuk memberikan gambaran bahwa rinitis alergi dan penyakit tiroid autoimun khususnya hipertiroidisme memiliki satu mata rantai yang saling berhubungan dari segi patofisiologi dan akan menentukan morbiditas dari penyakit tiroid autoimun tersebut.

\section{Laporan Kasus 1}

Pasien wanita, usia 64 tahun, datang ke Poliklinik THT-KL RSUP dr. Hasan Sadikin Bandung dengan keluhan hidung tersumbat sejak 4 bulan terakhir disertai dengan hidung berair, bersinbersin, nyeri kepala dan nyeri pada area dahi. Keluhan hidung ini dirasakan lebih dari 4 hari dalam seminggu, terutama saat terkena debu dan berada di lingkungan dengan udara dingin. Keluhan disertai benjolan di leher bagian depan sejak kurang lebih 15 tahun yang lalu yang awalnya kecil dan semakin lama semakin membesar namun tidak disertai rasa nyeri. Keluhan berdebar-debar dan tangan gemetar juga sering dirasakan oleh pasien sejak adanya benjolan tersebut. Akibat keluhan-keluhan tersebut pasien mengalami gangguan dalam beraktivitas dan terkadang terganggu kualitas tidurnya. Riwayat asma, hipertensi dan diabetes melitus disangkal, namun dalam keluarga pasien terdapat riwayat asma yaitu ayah kandung pasien.

Pada pemeriksaan fisik ditemukan kondisi umum dan pemeriksaan sistemik batas normal. Benjolan yang ada di regio leher anterior berukuran $10 \times 8 \times 7 \mathrm{~cm}$, teraba kenyal, tidak ada nyeri tekan, dan ikut bergerak saat menelan. Skor total gejala hidung pasien pada saat pertama kali datang adalah 6 dan dari wawancara dengan kuisioner SNOT-22 didapatkan hasil sebesar 44 terutama pada bagian keluhan hidung. Pemeriksaan nasoendoskopi didapatkan konka inferior bilateral hipertrofi disertai sekret seromukoid, septum deviasi ke kanan pada 1/3 tengah hingga ke posteroinferior, didapatkan contact point antara septum dengan konka inferior di kavum nasi kanan, prosesus unsinatus pada kedua sisi tidak mengalami edema, meatus media terbuka cukup dan ditemukan sekret seromukoid yang keluar dari meatus media. Pemeriksaan THT lainnya dalam batas normal.

Berdasarkan hasil anamnesis, pemeriksaan fisik serta penunjang ditegakkan diagnosis kerja rinosinusitis kronik tanpa nasal polip et causa suspek rinitis alergi persisten sedang berat dengan diagnosis banding rinitis hormonal 
disertai suspek struma nodosa toksik. Pasien kemudian diberikan edukasi untuk cuci hidung dengan larutan isotonik, serta diberikan terapi dengan antibiotik amoksisilin klavulanat tablet $3 \times 625 \mathrm{mg}$ per oral, cetirizin tablet $1 \times 10 \mathrm{mg}$ per oral dan flutikason furoat intranasal 2 kali per hari. Pasien disarankan untuk pemeriksaan kadar hormon tiroid (T3, fT4, TSHs), sidik tiroid, dan biopsi aspirasi jarum halus.

Hasil biopsi aspirasi jarum halus menunjukkan kesimpulan berupa adenomatous goiter bilateral dan limfadenitis kronik non spesifik bilateral. Hasil pemeriksaan kadar hormon tiroid T3 $3,5 \mathrm{ng} / \mathrm{mL}$, fT4 $1,6 \mathrm{ng} / \mathrm{dL}$, TSHs $<0,02 \mathrm{mIU} /$ $\mathrm{mL}$ dan kesimpulan hasil sidik tiroid adalah struma multinodosa (nodul hangat) toksik. Pasien kemudian dikonsulkan ke Poliklinik Endokrinologi Penyakit Dalam dan mendapatkan terapi tiamazol tablet $1 \times 20 \mathrm{mg}$ per oral, dan disarankan untuk dilakukan USG kelenjar tiroid. Hasil USG kelenjar tiroid dapat disimpulkan bahwa terdapat massa solid disertai kalsifikasi di tiroid bilateral sugestif keganasan, disertai dengan pembesaran multipel kelenjar getah bening di daerah leher bilateral. Pasien kembali kontrol ke Poliklinik Endokrin Penyakit Dalam dan tetap mendapatkan terapi tiamazol tablet 1 × $20 \mathrm{mg}$ per oral ditambah dengan propanolol tablet $3 \mathrm{x}$ $10 \mathrm{mg}$ per oral. Dilakukan pemeriksaan CT-scan sinus paranasal dengan dan tanpa kontras dengan hasil adanya deviasi septum nasi bagian anterior ke kanan; tidak tampak tanda-tanda sinusitis.

Tata laksana selanjutnya pada pasien ini adalah reduksi konka dengan radiofrekuensi dalam lokal anestesi, untuk mengurangi keluhan hidung tersumbat. Terapi yang diberikan kepada pasien setelah reduksi konka adalah antibiotik levofloksasin tablet 1 x $500 \mathrm{mg}$ per oral, cetirizine tablet $1 \times 10 \mathrm{mg}$ per oral, analgetik asam mefenamat tablet $3 \times 500 \mathrm{mg}$ per oral, flutikason furoat intranasal 2 kali per hari, dan edukasi untuk cuci hidung dengan larutan isotonik.

Satu bulan pasca penanganan terpadu baik rinosinusitis alergi maupun hipertiroidisme pada pasien ini ialah skor total gejala hidung berkurang dari 6 menjadi 4, penurunan skor SNOT-22 (perbaikan kualitas hidup) dari 44 menjadi 32, pemeriksaan nasoendoskopi konka inferior eutrofi, sekret serosa minimal, dan tidak ada contact point. Gejala gemetar dan palpitasi juga berkurang. Pasien kemudian dilakukan tes kulit tusuk dengan hasil positif terhadap kecoa.

\section{Laporan Kasus 2}

Pasien pria, usia 61 tahun, datang ke Poliklinik THT-KL RSUP dr. Hasan Sadikin Bandung setelah dikonsulkan dari Poliklinik Endokrinologi Penyakit Dalam dengan keluhan hidung tersumbat yang dirasakan hilang timbul sejak kurang lebih 6 tahun yang lalu. Keluhan ini disertai dengan hidung berair, bersin-bersin, rasa gatal pada hidung dan penciuman yang berkurang, dirasakan lebih dari 4 hari dalam seminggu terutama apabila pasien terkena debu. Saat keluhan-keluhan ini muncul dan semakin memberat, pasien sering merasakan nyeri kepala namun tidak ada nyeri pada area wajah. Akibat keluhan-keluhan tersebut pasien mengalami gangguan dalam beraktivitas dan terganggu kualitas tidurnya.

Pasien memiliki riwayat hipertiroidisme dalam pengobatan propiltiourasil (PTU) selama 8 tahun dan dilanjutkan dengan tiamazol sejak 7 tahun yang lalu. Riwayat asma dan diabetes melitus disangkal, namun pasien memiliki riwayat hipertensi terkontrol dengan pengobatan amlodipin 1 x 5 mg. Pada kakak kandung pasien didapatkan riwayat gatal-gatal apabila berada pada udara dingin.

Pada pemeriksaan fisik ditemukan kondisi umum dan pemeriksaan sistemik dalam batas normal, dengan tekanan darah 130/80 $\mathrm{mmHg}$. Skor total gejala hidung pasien adalah 10 dan dari wawancara dengan kuisioner SNOT-22 didapatkan hasil sebesar 43 terutama pada bagian gejala hidung. Pemeriksaan nasoendoskopi didapatkan konka inferior bilateral hipertrofi disertai sekret seromukoid, septum tidak deviasi, prosesus unsinatus pada kedua sisi tidak mengalami udem dengan meatus media yang terbuka cukup dan tidak ditemukan sekret yang keluar dari meatus media. Pemeriksaan THT lainnya dalam batas normal. Hasil pemeriksaan kadar hormon tiroid pada saat pasien datang pertama kali ke Poliklinik THT-KL sudah menunjukkan nilai normal (hasil pemeriksaan tanggal 27 November 2015 : T3 $1,7 \mathrm{ng} / \mathrm{mL}$, fT4 $1,2 \mathrm{ng} / \mathrm{dL}$, TSHs $1,7 \mathrm{mIU} / \mathrm{mL}$ ).

Berdasarkan hasil anamnesis, pemeriksaan fisik serta penunjang ditegakkan diagnosis rinosinusitis kronik tanpa nasal polip et causa suspek rinitis alergi persisten sedang berat dengan diagnosa banding rinitis hormonal disertai dengan penyakit Graves'. Pasien kemudian diberikan edukasi untuk cuci hidung dengan larutan isotonik, serta diterapi dengan amoksisilin klavulanat tablet 1 x $625 \mathrm{mg}$ per oral, cetirizin tablet $1 \times 10 \mathrm{mg}$ per oral dan flutikason furoat intranasal 2 kali per hari selama 4 minggu dengan evaluasi setiap 1 minggu sekali.

Selanjutnya dilakukan pemeriksaan hormon tiroid kembali dengan hasil yang juga normal (fT4 1,3 ng/dL dan TSHs 2,8 $\mathrm{mIU} / \mathrm{mL}$ ) sehingga bagian Endokrinologi Penyakit Dalam memutuskan untuk menghentikan pemberian 
tiamazol selama 3 bulan dan akan dilakukan evaluasi kadar hormon tiroid kembali 3 bulan yang akan datang.

Satu bulan pasca penanganan terpadu baik rinitis alergi maupun hipertiroidisme pada pasien ini adalah skor total gejala hidung berkurang dari 10 menjadi 7, penurunan skor SNOT-22 (perbaikan kualitas hidup) dari 43 menjadi 32, pemeriksaan nasoendoskopi konka inferior bilateral eutrofi, sekret serosa minimal. Gejala gemetar dan palpitasi juga berkurang. Pasien kemudian dilakukan tes kulit tusuk dengan hasil positif terhadap tungau debu rumah dan bulu anjing. Terapi yang sama dengan sebelumnya masih diberikan kepada pasien.

\section{Pembahasan}

Tirotoksikosis Graves' dipicu oleh thyroid stimulating autoantibodies hingga reseptor tirotropin (TSH) dan kemungkinan terkait dengan kondisi dominan dari T-helper 2 (Th2). Pada kenyataannya, dapat ditemukan bahwa terjadinya relaps dari tirotoksikosis berhubungan dengan meningkatnya antibodi reseptor TSH dan eosinofil perifer setelah terjadinya serangan rinitis alergi dimana rinitis alergi ini merupakan penyakit yang terjadi kondisi predominan dari Th2. ${ }^{7}$

Oleh karena itu, dapat diperkirakan bahwa peningkatan peripheral Th2-derived cytokines pada penyakit alergi dapat memperburuk penyakit Graves'. Pada kenyataannya, tipe respon imun Th2 kemungkinan penting dalam patogenesis penyakit Graves' karena serum IL-5, sitokin Th2, dan serum CD30 terlarut, yang terutama disekresi dari sel-sel Th2, jumlahnya meningkat pada penyakit Graves'. Selain itu, proporsi dari sel-sel Th2 lebih tinggi pada limfosit intratiroidal dibandingkan pada limfosit darah tepi pasien. Kenaikan serum IgE ditemukan lebih dari 30\% pasien dengan penyakit Graves', dan kadar serum antibodi reseptor TSH secara signifikan lebih tinggi pada pasien yang mengalami kenaikan kadar IgE dibandingkan pada pasien yang memiliki kadar serum IgE normal. ${ }^{7}$ Sitokin Th2 menstimulasi eosinofil dan baru-baru ini ditemukan hasil hitung eosinofil perifer meningkat pada pasien tirotoksik dengan penyakit Graves'. Pada penelitian ini didapatkan peningkatan serum Eosinophil-Derived Neurotoxin (EDN) pada pasien dengan penyakit Graves' yang tidak diobati dan terdapat hubungan yang positif antara kadar serum EDN dengan titer serum antibodi reseptor TSH. Data-data ini membuktikan bahwa penyakit alergi terkait erat dengan penyakit Graves' dan bahwa respon imun tipe Th2 penting dalam patogenesis penyakit Graves' ${ }^{7,8}$

Berdasarkan telusur jurnal penelitian yang dilakukan oleh Amino et al, bahwa pengaturan imunomodulasi pasien rinitis alergi akan mengurangi penggunaan konsumsi obat pada penyakit Graves'. ${ }^{8}$ Penelitian lain oleh Takeoka et al memperlihatkan rinitis alergi musiman akan menginduksi peningkatan serum autoantibodi antitiroid. ${ }^{9}$

Pada kasus pertama terlihat dengan penegakan diagnosis yang baik serta penatalaksanaan yang terpadu antara rinosinusitis alergi dan hipertiroidisme memberikan hasil terapi yang cukup baik. Selain sangat menurunkan gejala rinosinusitis alergi, juga menurunkan gejala tiroid. Pada kasus kedua, penatalaksanaan terpadu antara rinosinusitis alergi dan hipertiroidisme terlihat sangat baik dengan berkurangnya gejala rinosinusitis alergi maupun hipertiroidisme disertai normalnya kadar hormon tiroid yang diikuti oleh penghentian konsumsi obat-obatan antitiroid.

Penelitian ini memperlihatkan bahwa rinitis alergi yang merupakan suatu proses inflamasi terlokalisasi dihidung dan mata apabilamelibatkan kelenjar limfe menuju ke glandula tiroid dan mukosa respiratori akan menyebabkan produksi sitokin Th2 secara tidak langsung dan produksi autoantibodi oleh sel B, serta produksi IL-4 yang akan menstimulasi produksi IgG1, IgG3 dan IgG4 bersamaan juga dengan IgE. Sitokin Th2 lainnya yaitu IL-13 akan menstimulasi IgE dan IgG4, sehingga disimpulkan reaksi lokal alergi pada hidung dan mata akan menstimulasi reaksi imun yang predominan Th2 pada kelenjar limfe dan dapat mengaktivasi produksi autoantibodi pada glandula tiroid. ${ }^{9}$

Pada kedua kasus ini, penanganan terpadu rinosinusitis alergi dan hipertiroidisme dapat menurunkan gejala dari kedua penyakit tersebut dan mengurangi konsumsi obat antitiroid.

\section{Daftar Pustaka}

1. Guner SN, Gokturk B, Kilic M, Ozkiraz $\mathrm{S}$. The prevalences of allergic diseases in rural and urban areas are similar. Allergol Immunopathol (Madr). 2011;39(3):140-4.

2. Pawankar R, Bunnag C, Khaltaev N, Bousquet J. Allergic Rhinitis and Its Impact on Asthma in Asia Pacific and the ARIA Update 2008. World Allergy Organization Journal. 2012;5:212-7.

3. Moeis RM, Sudiro M, Herdiningrat S. Allergic Rhinitis Patient Characteristics in Dr. Hasan Sadikin General Hospital Bandung Indonesia. Althea Medical Journal. 
2014;1(2):75-80.

4. Holt K. Graves' Disease : Clinical Pathophysiology, Presentation and Treatment Options. Journal of Practical Nursing. 2010;60:3-13.

5. Molnár I, Kelemen E, Somogyiné-Vári E. The Prevalence and Characteristics of Allergy in Autoimmune Thyroid Diseases. J Clin Cell Immunol. 2015;6(2):2.

6. Reisacher WR. Prevalence of autoimmune thyroid disease in chronic rhinitis. Ear, Nose \& Throat Journal. 2008;87(9):524-7.

7. Hidaka Y, Kimura M, Izumi Y, Takano T, Tatsumi K, Amino N. Increased Serum Concentration of Eosinophil - Derived Neurotoxin in Patients with Graves' Disease. Thyroid. 2003;13(2):129-32.
8. Molnar I, Kelemen E, Vari ES. The Prevalence and Characteristics of Allergy in Autoimmune Thyroid Diseases. Journal of Clinical \& Cellular Immunology. 2015;6(2):2-6.

9. Gurlek F, Tasdemir E. Evaluating of Thyroid Function Tests and Thyroid Autoantibodies in Patients with Allergic Rhinitis. Istanbul Med. 2017; 18:139-44. 